\title{
DAMPAK PELATIHAN PETANI TERHADAP KINERJA USAHATANI KEDELAI DI JAWA TIMUR
}

\author{
Apri Kuntariningsih ${ }^{1}$ dan Joko Mariyono ${ }^{2}$ \\ ${ }^{1}$ Mahasiswa Program Pascasarjana, Universitas Muhammadiyah Malang \\ ${ }^{2}$ Fakultas Ekonomi, Universitas Pancasakti - Tegal \\ E-mail: aprikunt@gmail.com
}

\begin{abstract}
ABSTRAK. Penelitian ini menganalisis kinerja usahatani kedelai di Jawa Timur, dengan penekanan pada dampak pelatihan petani. Dampak dari pelatihan ini diharapkan dapat meningkatkan kinerja usahatani kedelai, yang diukur dengan peningkatan produksi dan keuntungan. Fungsi produksi dan fungsi keuntungan yang sederhana digunakan dalam penelitian ini. Data dikumpulkan dengan wawancara pribadi, yang dipandu dengan kuesioner semiterstruktur. Tiga kabupaten: Jember, Nganjuk dan Ngawi Jawa Timur terpilih sebagai lokasi penelitian. Lokasi ini adalah daerah produksi kedelai di Jawa Timur. Usahatani yang dijalankan selama 2010 terpilih sebagai objek kajian ini. Pendekatan regresi-berganda digunakan untuk memperkirakan fungsi produksi dan keuntungan yang dibangun. Hasil menunjukkan bahwa pelatihan telah berdampak positif terhadap produksi dan keuntungan dari usaha tani kedelai, demikian juga tingkat pendidikan dan pengalaman. Petani yang menjalankan usahataniinya di lahan sewa menunjukkan tingkat produksi dan keuntungan yang lebih rendah. Pada akhirnya, kenaikan pendapatan petani setelah mengikuti pelatihan diharapkan meningkatkan kesejahteraan keluarga petani.
\end{abstract}

Kata kunci: analisis ekonomi, usahatani kedelai, dampak pelatihan, pendekatan ekonometrik

\section{IMPACT OF FARMERS' TRAINING ON PERFORMANCE OF SOYBEAN FARMING IN EAST JAVA}

\begin{abstract}
This study analyzed performance of soybean farming in East Java, which emphasized on the impact of farmers' training. The impact of training was expected to enhance the performance of soybean farming, measured with increase in production and net-revenue. Simple production and profit functions were employed in this study. Data were collected using personal interview, guided with semi-structured questionnaire. Three districts: Jember, Nganjuk and Ngawi of East Java were selected as study sites. These locations were the soybean-production areas in East Java. Farming operation during 2010 was selected as object of study. A multi-regression approach was employed to estimate the established production and profit functions. The results show that training has positively impacted on both production and profit of soybean farming, as well as level of education and experience. Farmers operating share tenancy showed lower level of production and profit. Eventually, increase in farmers' income after training is expected to enhance farmers' welfare.
\end{abstract}

Keywords: economic analysis, soybean farming, impact of training, econometric approach

\section{PENDAHULUAN}

Produksi pangan saat ini menjadi terbatas karena kekurangan lahan pertanian, air bersih, dan kekurangan pupuk yang bergantung pada energi fosil baik untuk produksi atau pertambangan dan pengolahan. Kekurangan sumber daya ini semakin meningkat seiring dengan pesatnya laju pertumbuhan jumlah penduduk di seluruh dunia. Kekurangan sumber daya dan tingkat keparahan kekurangan gizi yang paling serius terjadi di Afrika dan Asia dimana terjadi pertumbuhan penduduk paling besar. Masalah nyata yang dihadapi manusia untuk kelangsungan hidup dalam banyak hal, termasuk kesehatan dan penyediaan bahan pangan yang cukup. Dunia ini sedang menghadapi masalah populasi yang berlebihan, dan dampaknya sudah dirasakan di planet ini, khususnya di Asia dan Afrika (Pimentel, 2012).

Kedelai merupakan salah satu komoditi pangan utama yang menyehatkan karena mengandung protein tinggi dan memiliki kandungan kolesterol yang rendah. Seiring dengan 
laju pertumbuhan penduduk, kebutuhan akan komoditi kedelai terus meningkat dari tahun ke tahun baik sebagai bahan pangan utama, pakan ternak maupun sebagai bahan baku industri skala industri hingga skala rumah tangga. Di Indonesia, rata-rata kebutuhan kedelai setiap tahun kira-kira 2.300.000 ton. Untuk memenuhi kebutuhan kedelai tersebut, produksi dalam negeri saat ini baru mampu memenuhi kirakira 907.031 ton, atau sekitar 41,22\% dari kebutuhan, sedangkan kekurangannya berasal dari impor (BPS, 2010). Besarnya impor tersebut, menyebabkan kehilangan devisa negara yang cukup besar dan sangat rentan terhadap ketahanan pangan nasional.

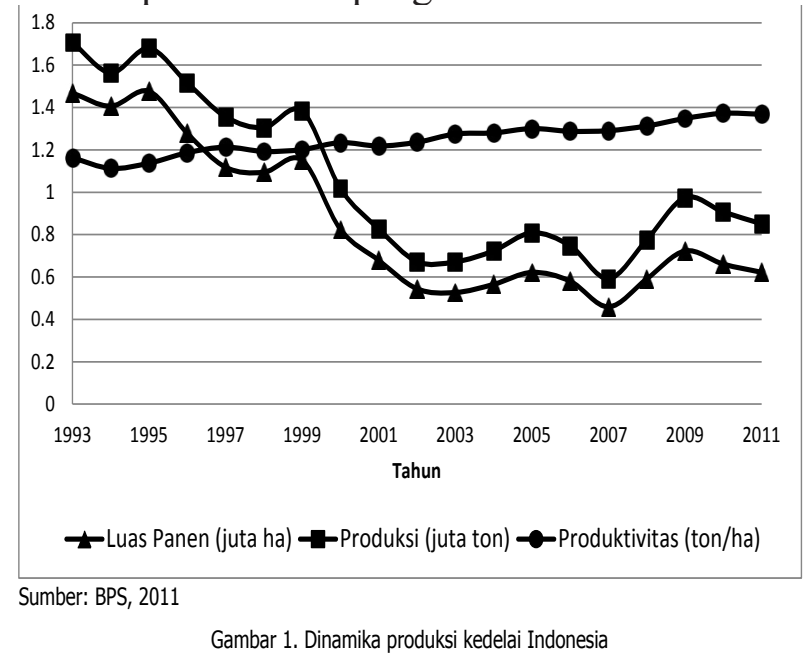

Luas panen dan produksi kedelai Indonesia cenderung turun sejak tahun 1993. Gambar 1 menunjukkan bahwa selama kurun waktu 1993-2011, luas panen dan produksi kedelai turun sebanyak 50\%. Menurunnya luas panen tersebut menyebabkan produksi kedelai Indonesia menjadi rendah. Rendahnya produksi kedelai di dalam negeri antara lain disebabkan masih rendahnya produktivitas, di tingkat petani rata-rata hanya mencapai 1,3 ton/ ha (BPS, 2011). Terlihat tidak ada peningkatan produktivitas yang signifikan selama kurun waktu tersebut. Padahal, potensi produksi beberapa varietas unggul dapat mencapai 2-3,5 ton/ha. Rendahnya produkstivitas ini karena belum diterapkannya teknologi spesifik lokasi. Selain itu harga kedelai di tingkat petani yang berfluktuatif dan cenderung rendah merupakan penyebab utama berkurangnya minat petani menanam kedelai (Arisudi dan Gapor, 2008).

Pada tahun 2011-2012, berbagai media massa mengemukakan kelangkaan kedelai dan kenaikan harga kedelai sebagai isu nasional.
Oleh karena itu peningkatan produksi dan produktivitas kedelai menjadi sangat penting, terutama untuk mengurangi ketergantungan kedelai impor. Pemberdayaan petani merupakan salah satu cara yang strategis untuk dapat meningkatkan produksi kedelai, karena dengan petani yang tangguh, diseminasi teknologi pertanian akan mudah diadopsi oleh petani. Teknologi yang unggulpun tidak akan banyak berguna jika tidak diadopsi oleh petani. Satu hal yang penting dalam diseminasi teknologi baru adalah adanya peningkatan produksi dan keuntungan dari usahatani yang diperoleh petani. Di Jawa Timur, telah dilakukan pelatihan petani kedelai, agar petani dapat menerapkan teknologi yang tepat guna, sehingga produksi kedelai diharapkan meningkat. Pertanyaan penelitian ini adalah sejauh mana dampak pelatihan telah dapat meningkatkan produksi kedelai dan keuntungan usahatani kedelai. Hipotesis penelitian ini adalah bahwa pelatihan akan mampu meningkatkan produksi kedelai, sekaligus meningkatkan keuntungan usahatani kedelai. Berdasarkan pertanyaan dan hipotesis tersebut, tujuan kajian ini adalah menganalisis dampak pelatihan kepada petani sebagai upaya peningkatan produksi dan kentungan usahatani kedelai di Jawa Timur.

Pelatihan petani dengan metoda sekolah lapangan (SL) telah diperkenalkan di Indonesia sejak tahun 1980an melalui pelatihan teknologi PHT (Rolling dan van de Fliert, 1994). Walaupun secara nasional program pelatihan PHT sudah selesai, pelatihan dengan metoda SL sudah banyak diadaptasi untuk menyampaikan teknologi baru kepada petani. Khusus pelatihan teknologi PHT, Indonesia menyatakan bahwa program pelatihan telah berhasil. Petani telah mengadopsi teknologi dan ada indikasi terjadinya difusi pengetahuan diantara petanipetani Indonesia. Indonesia menjadi salah satu pemimpin dalam penerapan teknologi PHT di Asia karena telah membantu petani untuk mengurangi ketergantungan mereka pada pestisida dan meningkatkan hasil panen mereka (van den Berg, 2004). Hal ini juga secara dramatis mengurangi dampak negative pestisida pada manusia dan pencemaran lingkungan (Agrochemical Report, 2002).

Sejak keberhasilan program PHT di negeri ini, telah dilakukan berbagai kajian 
dampak pelatihan, baik di Indonesia maupun di negara-negara berkembang lainnya Kajian-kajian tersebut dilakukan dengan berbagai jenis pendekatan dan indikator penilaian yang berbeda-beda. Beberapa penelitian mengkonfirmasi keberhasilan tersebut (Irham, 2001; 2002, van den Berg, 2004; van den Berg dan Jiggins, 2007) dan be-berapa lainnya mengkritik (Feder et al., 2004a; 2004b; Mariyono, 2009). Dampak yang lebih luas dari pelatihan pada mata pencaharian telah menarik perhatian para ahli pembangunan. Ada dua dampak utama dari pelatihan tersebut, yaitu dampak langsung dan dampak perkembangan. Akhirnya, dampak tersebut terus mengembangkan mata pencaharian petani. Seperti yang ditunjukkan oleh van den Berg dan Jiggins (2007), adanya pelatihan telah menguntungkan petani melalui dampak langsung maupun dampak perkembangan. Lilja dan Dixon (2008) menganalisis dampak yang lebih luas dari pelatihan yang menunjukkan bahwa dengan pemberdayaan petani, kemiskinan di pedesaan telah berkurang di banyak negara.

Mengingat pesan mendasar dari pelatihan adalah untuk memberdayakan petani atau untuk meningkatkan pengetahuan petani, maka diperlukan evaluasi untuk melihat dampak dari pelatihan tersebut. Petani yang telah selesai menjalani pelatihan telah ditingkatkan dalam hal pengetahuan budidaya tanaman yang lebih baik. Namun, difusi teknologi dan pengetahuan dari para petani yang telah terlatih kepada petani lain tidak terjadi, karena petani yang sudah dilatih gagal dalam menyampaikan pesan yang rumit yang diperoleh dari proses pelatihan (Feder et al., 2004a). Difusi teknologi akan terjadi jika petani mempunyai kepemimpinan yang kuat dalan menyampaikan opini (Feder dan Savastano, 2006). Godtland et al. (2004) melakukan studi dampak pelatihan pada pengetahuan petani kentang di Peru. Mereka menemukan bahwa petani yang berpartisipasi dalam pelatihan mampu menjelaskan lebih lanjut tentang pengelolaan hama dan penyakit pertanian kentang daripada rekan-rekan mereka.

Dengan sudut pandang yang berbeda, analisis ekonomi mengenai dampak pe- latihan adalah pada penggunaan pestisida dan hasil produksi. Mancini dan Jiggins (2008) menggunakan pendekatan penelitian partisipatif untuk menggambarkan bahwa pemahaman yang lebih dalam penanganan bahaya akibat pestisida memang memicu perubahan sikap peserta pelatihan terhadap pestisida. Mereka menemukan bahwa petani yang menjadi anggota kelompok pelatihan secara signifikan lebih baik daripada petani non-anggota. Hal ini karena penanganan yang lebih baik dari aplikasi pestisida oleh kelompok yang telah mendapat pelatihan. Sebuah studi oleh Mariyono et al. (2010) menunjukkan bahwa perubahan dari teknologi yang berbasis teknologi Revolusi-Hijau ke teknologi yang berbasis teknologi PHT dalam budidaya produksi padi di Indonesia telah membawa kemajuan teknologi yang menghemat bahan kimia pertanian secara signifikan. Artinya, telah terjadi kenaikan produksi padi dan penurunan penggunaan bahan kimia secara bersamaan. Hal ini konsisten dengan hasil kajian lainnya bahwa kontribusi pelatihan dalam menurunkan penggunaan pestisida sangat signifikan (Mariyono, 2006). Namun demikian, penurunan penggunaan pestisida di Indonesia tidak terjadi secara instan setelah pelaksanaan program pada tahun 1986, tetapi lebih karena tingkat kinerja dan kualitas pelatihan masih tergolong rendah sampai sedang (Mariyono, 2009).

Kritik datang dari Feder et al. (2004b) yang menggunakan data tingkat petani di Indonesia dan model analisis yang kompleks. Mereka melaporkan bahwa tidak ada perbedaan dalam hal perubahan penggunaan pestisida dan hasil padi antara petani yang dilatih dengan yang tidak dilatih. Yamasaki dan Resosudarmo (2008) memperbaiki temuan Feder et al. (2004b) dan menemukan bahwa pelatihan berdampak sebagian pada produksi padi, tetapi tidak berdampak pada penggunaan pestisida. Namun, Prety dan Waibel (2005) menjelaskan bahwa kasus yang terjadi di Indonesia ini bukan karena faktor teknologi PHT yang disampaikan melalui pelatihan, tetapi disebabkan oleh faktor administrasi dan birokrasi yang bertele-tele waktu itu. Pendapat ini sejalan 
dengan temuan Mariyono (2009) bahwa kualitas pe-laksanaan pelatihan yang rendah oleh karena proses birokrasi pencairan dana yang sering terlambat. Untuk tanaman kedelai, dampak pelatihan telah meningkatkan efisiensi teknis usahatani kedelai (Mariyono, 2011). Artinya, dengan jumlah input yang sama, petani yang telah mendapat pelatihan dapat meningkatkan produksi kedelai. Hal ini didukung oleh penelitian yang lain bahwa pelatihan dapat meningkatkan produksi dan menurunkan biaya produksi (Mariyono dan Rachmansyah, 2010).

\section{METODE}

Mengacu pada metoda penelitian telah di-terapkan oleh Mariyono dan Kuntrarinigsih (2009), kajianinitermasukexplanatoryresearch, yaitu penelitian yang menyoroti hubungan antar variabel penelitian dan menguji hipotesis yang telah dirumuskan sebelumnya. Uraian dalam penelitian ini mengandung deskripsi, sehingga sebagai penelitian relasional, titik beratnya terletak pada penjelasan hubungan antar variabel yang diteliti. Explanatory research dapat dilakukan karena pengetahuan tentang permasalahan yang dihadapi sudah cukup tersedia dan sudah ada berbagai penelitian empiris yang menguji hipotesis tertentu. Oleh karena itu penelitian jenis ini akan menentukan sifat dan hubungan antara satu atau lebih gejala atau variabel dependen dengan satu atau lebih variabel independen.

Subyek penelitian adalah petani kedelai, dengan status kepemilik dan sebagai penggarap. Lokasi kajian ini adalah di wilayah Jember, Nganjuk dan Ngawi, Provinsi Jawa Timur. Propinsi ini di pilih sebagai lokasi karena merupakan penghasil kedelai yang ptensial. Untuk menentukan jumlah sampel yang digunakan dalam penelitian ini adalah menggunakan stratified rondom sampling. Jumlah sampel yang akan diambil sebanyak 60 orang petani yang berasal dari 6 kelompok tani yang sudah mengukuti pelatihan. Masingmasing kelompok tani diwakili oleh 10 orang.

Teknik pengumpulan data dilakukan dengan cara wawancara dengan responden, dipandu dengan menggunakan kuesioner. Observasi ini dilakukan oleh peneliti secara langsung pada obyek atau lapangan serta mengadakan pencatatan secara sistematis mengenai sesuatu hal yang penting dalam kaitannya dengan data-data kuantatif. Data mengenai keadaan sosial ekonomi petani dikumpulkan. Data primer diperoleh dari petani responden dengan mengadakan wawancara langsung dan berpedoman pada daftar pertanyaan yang telah dipersiapkan. Data yang dicatat dalah data usahatani yang terjadi pada tahun 2010. Pengambilan data dilakukan dua kali. Pengambilan data yang pertama dilakukan sebelum pelatihan. Semua kegiatan usahatani dicatat dalam kuesioner. Pengambilan data yang kedua dilakukan setelah selesai menjalani pelatihan. Cara pengambilan data dilakukan seperti pengambilan data yang pertama. Banyak data yang dicatat dalam pengumpulan data, tetapi dalam kajian ini, data yang digunakan mencakup: (1) identitas petani responden, (2) keterlibatan petani dalam pelatihan, (3) data yang terkait dengan produktivitas: biaya pengunaan benih, pupuk, pestisida, tenagakerja, hasil panen, (4) data yang terkait dengan sekolah lapangan yaitu pengetahuan, sikap, dan ketrampilan.

Teknis analisis data menggunakan metode "sebelum dan sesudah" pelatihan. Teknik ini sangat baik untuk mengevaluasi perubahan yang terjadi oleh suatu kebijakan publik (Gittinger, 1982). Analisis dengan metode "tanpa dan dengan" pelatihan pernah dilakukan oleh Mariyono dan Kuntariningsih (2007) untuk mengevaluasi pelatihan yang hasilnya menunjukkan tidak ada perbedaan. Hal ini terjadi karena telah terjadi difusi antara petani yang pernah dan belum mengikuti pelatihan. Selain itu, membandingkan petani yang mengikuti program pemerintah dengan yang tidak mengikuti adalah tidak adil karena pemilihan petani untuk melaksanakan program pemerintah dipilih secara tidak acak dan mengikuti kriteria tertentu. Biasanya, petani yang dipilih untuk program pemerintah adalah petani yang sudah maju dan kooperatif. Dengan demikian tanpa adanya pelatihanpun, petani yang ikut program pemerintah sudah lebih unggul dibanding dengan petani yang tidak ikut program (Feder et al. 2004b)

Dengan mengacu pada teori ekonomimikro yang dikemukakan oleh Pyndick dan 
Rubinfeld (2008) analisis ini menggunaan pendekatan secara ekonometrik yaitu dengan menggunakan model fungsi produksi dan keuntungan usahatani. Fungsi produksi menggunakan dua bentuk yaitu fungsi produksi Cobb-Douglas yang memasukkan faktor produksi berupa modal $(K)$ dan tenaga kerja $(N)$ dalam pengaruhnya terhadap produksi $Q$. Bentuk fungsi produksi CobbDouglas secara matematis ditulis:

$$
Q=K^{\alpha_{1}} N^{\alpha_{2}} e^{u}
$$

Bentuk fungsi ini sering digunakan dalam menganalisis dalam bidang pertanian. Namun dengan menggunakan fungsi ini, faktor lain yaitu: pendidikan petani, pengalaman petani, status petani tidak dapat diketahui pengaruhnya. Padahal faktor tersebut sangat penting dalam mempengaruhi produksi karena mempunyai pengaruh langsung terhadap kemampuan manajerial petani. Untuk mengatasi kelemahan tersebut digunakan power function of production yang juga sering digunakan dalam analisis fungsi produksi bidang pertanian. Fungsi produksi tersebut dalam bentuk matematis adalah:

$$
Q=A \prod_{i=1}^{n} X_{i}^{\beta i} \prod_{j=1}^{m} Z_{j}^{\delta j} e^{u}
$$

Dimana $Q$ adalah produksi, $A$ merupakan koefisien tetap yang menunjukkan kondisi teknologi dan manajemen, $X_{\mathrm{i}}$ adalah input variabel, $Z_{j}$ adalah keadaan sosialekonomi petani, $\boldsymbol{e}$ adalah bilangan natural, $u$ adalah error term. Perbaikan teknologi dan manajemen melalui pelatihan diharapkan akan mempengaruhi nilai $A$. Jika pelatihan menghasilkan perbaikan manajemen, maka adanya pelatihan akan mempengaruhi produksi $Q$ melalui perubahan nilai $A$, sehingga perbaikan manajemen setelah pelatihan dapat dilihat dengan bantuan variabel dummy $\left(D_{1}=1\right.$ untuk setelah pelatihan) yang menunjukkan perbedaan antara sebelum dan sesudah pelatihan, sehingga bentuk fungsi (1) dan (2) menjadi:

$$
Q=\mathbb{K}{ }^{\alpha_{1}} N^{\alpha_{2}} e^{\alpha_{3} D_{1}} e^{u}
$$

$$
Q=A \prod_{i=1}^{n} X_{i}^{\beta i} \prod_{j=1}^{m} Z_{j}^{\delta j} e^{\gamma D_{1}} e^{u}
$$

Tetapi kondisi manajemen juga dipengaruhi oleh status petani dalam memperoleh akses lahan (Acharya, 1999), sehingga perbedaan status akan mempengaruhi produksi melalui perubahan nilai $A$ akibat perbedaan status. Keadaan ini dapat dilihat dengan variabel dummy $(D 2=1$ untuk penyewa). Dengan demikian fungsi produksi (4) di atas berubah menjadi:

$$
Q=A \prod_{i=1}^{n} X_{i}^{\beta i} \prod_{j=1}^{m} Z_{j}^{\delta j} e^{\gamma_{1} D_{1}} e^{\gamma_{2} D_{2}} e^{u}
$$

Dimana D1 variabel dummy untuk pelatihan, dan D2 variabel dummy untuk status petani terhadap akses lahan. Sebelum diestimasi, fungsi produksi (3) dan (5) dalam bentuk fungsi berpangkat ditransformasi ke bentuk logaritma sehingga diperoleh fungsi produksi yang berbentuk linier dalam parameter, yaitu:

$$
\bar{Q}=\bar{A}+\alpha_{1} \bar{K}+\alpha_{2} \bar{N}+\alpha_{3} D_{1}+u
$$

dan

$$
\begin{aligned}
& \bar{Q}=\bar{A}+\sum_{i=1}^{n} \beta_{i} \bar{X}_{i}+ \\
& \sum_{j=1}^{m} \delta_{j} \bar{Z}_{j}+\gamma_{1} D_{1}+\gamma_{2} D_{2}+u
\end{aligned}
$$

Dimana tanda garis atas pada setiap variabel mewakili operasi logaritma. Fungsi produksi (6) dan (7) dapat diestimasi dengan menggunakan regresi berganda. Selain analisis fungsi produksi, juga dilakukan analisis fungsi keuntungan. Hal ini didasarkan pada keadaan bahwa perbaikan manajemen usahatani melalui pelatihan bertujuan untuk meningkatkan keuntungan dengan memperbaiki efisiensi penggunaan input. Seperti dijelaskan dalam teori produksi bahwa keuntungan usahatani merupakan selisih antara total nilai produksi yang diperoleh $(T R)$ dan total biaya $(T C)$ yang dikeluarkan, yaitu:

$$
\pi \equiv R-\mathbb{C}=Q\left(X_{i}, Z_{j}\right)-W_{i} X_{i}-W_{j} Z_{j}
$$

Dimana, $P$ merupakan harga produk, $W_{i}$ dan $W_{j}$ harga faktor input. Jadi besarnya keuntungan dipengaruhi oleh harga produk, harga faktor input, penggunaan input tetap, 
penggunaan input variabel, dan manajemen. Analisis fungsi keuntungan dilakukan secara linier, yang secara matematis ditulis:

$$
\pi=\theta_{0}+\sum_{i=1}^{n} \theta_{i} X_{i}+\sum_{j=1}^{m} \theta_{j} Z_{\jmath} \varphi_{1} D_{1}+\varphi_{2} D_{2}+\imath(9)
$$

Karena penelitian ini dilakukan secara cross sectional, maka semua petani menghadapi harga kedelai dan harga input variabel yang sama, sehingga variabel harga dianggap tetap dan tidak masuk dalam model analisis. Perlu diketahui bahwa manejemen usahatani tidak hanya dipengaruhi oleh pelatihan, tetapi juga dipengaruhi oleh pengalaman petani dalam usahatani dan pendidikan formal petani. Oleh karena itu faktor pengalaman dan pendidikan masuk dalam model analisis.

Variabel terikat adalah variabel yang dipengaruhi oleh variabel lain, yang dalam penelitian ini adalah:

1. Produksi $(Q)$, yaitu jumlah produksi kedelai yang dihasilkan dalam satu musim tanam yang diukur dengan satuan kilogram $(\mathrm{kg})$.

2. Keuntungan $(\pi)$, yaitu keuntungan usahatani kedelai dalam satu musim tanam yang diukur dengan satuan rupiah.

Variabel bebas $(X)$ adalah variabel yang tidak dipengaruhi oleh variabel lain. Dalam penelitiann ini variabel bebasnya adalah:

1. Modal $(K)$, yaitu total nilai uang yang dikeluarkan untuk pengadaan input, yang diukur dengan satuan rupiah.

2. Tenaga kerja $(N)$, yaitu jumlah tenaga kerja yang dipekerjakan mulai dari persiapan lahan sampai panen, yang diukur dengan satuan orang hari. Tenaga kerja dapat berasal dari dalam maupun luar keluarga.

3. Lahan $(L)$, yaitu luas lahan yang diusahakan untuk tanaman kedelai, diukur dengan satuan hektar (ha)

4. Benih kedelai $(B)$, yaitu jumlah penggunaan benih kedelai yang diukur dengan satuan kilogram $(\mathrm{kg})$

5. Pupuk $(F)$, yaitu nilai pupuk yang digunakan untuk usahatani selama satu musim tanam, yang diukur dengan satuan rupiah. Satuan ini digunakan dengan dasar pertimbangan bahwa petani menggunakan jenis pupuk yang berbeda-beda, sehingga besarnya biaya pupuk merupakan proxy dari jumlah penggunaan pupuk.
6. Pestisida $(P)$, yaitu nilai pestisida yang digunakan untuk usahatani selama satu musim tanam, yang diukur dengan satuan rupiah. Satuan ini digunakan dengan dasar pertimbangan bahwa petani menggunakan jenis pestisida yang berbeda-beda, sehingga besarnya biaya pestisida merupakan proxy dari jumlah penggunaan pestisida.

7. Pendidikan petani $(E D)$, yaitu lamanya petani dalam memperoleh pendidikan formal, diukur dengan satuan tahun. Jika petani lulus sekolah dasar maka mempunyai nilai 6 , jika lulus sekolah lanjutan pertama mempunyai nilai 9 , dan jika lulus sekolah lanjutan atas mempunyai nilai 12 .

8. Pengalaman $(E X)$, didekati dengan umur petani mencerminkan pengalaman dalam berusahatani dengan asumsi bahwa petani merupakan pekerjaan pokok dari awal. Pengalaman petani ini diukur dengan satuan tahun.

9. Status petani $\left(D_{1}\right)$, yaitu status petani terhadap akses lahan pertanian. Variabel ini diukur dengan variabel dummy dengan nilai satu untuk penyewa penggarap.

10. Pelatihan $\left(D_{2}\right)$, yaitu keadaan petani sebelum dan sesudah mengikuti pelatihan. Variabel ini diukur dengan variabel dummy dengan nilai satu untuk setelah pelatihan.

11. Variabel lain yang tidak dapat terukur diwakili misalnya faktor iklim cuaca dan kondisi alam lainnya diwakili oleh error term (u), dan faktor lain yang tidak masuk dalam analisis dianggap tetap.

Estimasi fungsi produksi dan kentungan dilakukan dengan regresi linier. Tatacara análisis mengikuti petunjuk yang disarankan oleh Wooldridge (2009). Hasil análisis yang disajikan telah melalui uji diagnostik, sehingga hasil análisis layak dan dapat dipercaya.

\section{HASIL DAN PEMBAHASAN}

\section{Fungsi Produksi}

Hasil analisis dengan menggunakan fungsi produksi Cobb-Douglas dapat dilihat pada persamaan di bawah ini: 
$\bar{Q}=-2,8+0, \Theta \bar{K}+0, \bar{\Phi} \bar{N}+0, \emptyset \quad D_{1}$

$\left(-6.34^{\mathrm{a}}\right)\left(16.33^{\mathrm{a}}\right)\left(4.20^{\mathrm{a}}\right)\left(2.00^{\mathrm{b}}\right)$

$\mathrm{R}^{2}=0.8485 \quad \mathrm{~F}=168.02^{\mathrm{a}}$

Keterangan: garis di atas variabel menunjukkan operasi logartima; angka dalam kurung adalah nilai t-hitung, ${ }^{\text {a) }}$ nyata pada $0.01{ }^{b}$ ) nyata pada 0.05

Dari hasil estimasi fungsi produksi Cobb-Douglas di atas dapat diketahui bahwa $85 \%$ produksi kedelai $(Q)$ ditentukan oleh penggunaan modal, tenaga kerja dan dampak pelatihan, yang secara keseluruhan berpengaruh sangat signifikan terhadap produksi kedelai. Secara parsial, penggunaan modal sangat signifikan dalam menentukan produksi kedelai. Jika penggunaan modal naik sebesar $10 \%$ akan meningkatkan produksi sebesar $6,87 \%$. Penggunaan tenaga kerja berpengaruh sangat signifikan dalam menentukan produksi kedelai. Jika penggunaan tenaga kerja meningkat sebesar $10 \%$, maka akan meningkatkan produksi sebesar 1,63\%. Sedangkan pelatihan berpengaruh positif signifikan terhadap produksi kedelai. Hasil ini menunjukkan bahwa setelah mengikuti pelatihan, petani dapat meningkatkan produksi kedelaianya. Peningkatan produksi ini terjadi karena petani menjadi lebih mampu dalam menerapkan teknologi, memilih factor produksi yang lebih tepat, dan melakukan pemeliharaan tanaman yang lebih baik.

Fungsi produksi Cobb-Douglas yang diestimasi di atas tidak dapat membedakan input yang signifikan dan yang tidak signifikan. Keadaan ini menyulitkan, karena jika akan meningkatkan produksi harus dilakukan dengan menambah modal untuk meningkatkan semua input. Disamping itu, karakteristik petani juga tidak dapat dilihat dari fungsi Cobb- Douglas. Untuk melihat pengaruh masing-masing penggunaan input dan keadaan kualitas sumberdaya manusia terhadap produksi secara bersama-sama, dilakukan dengan pengembangan fungsi produksi Cobb-Douglas. Hasil analisis fungsi produksi kedelai dapat dilihat pada Tabel 1.
Tabel 1. Hasil estimasi fungsi produksi pada usahatani kedelai

\begin{tabular}{|c|c|c|c|}
\hline No & Variabel independen & Koefisien regresi & Nilai t-hitung \\
\hline 1 & Konstanta & 3,9963 & $8,51^{\mathrm{a}}$ \\
\hline 2 & Luas lahan (L) & 0,5242 & $6,85^{\mathrm{a}}$ \\
\hline 3 & $\operatorname{Benih}(B)$ & 0,2776 & $4,83^{\mathrm{a}}$ \\
\hline 4 & Tenaga kerja $(M)$ & 0,1309 & $2,74^{\mathrm{a}}$ \\
\hline 5 & Pupuk $(F)$ & 0,0105 & $1,02^{n}$ \\
\hline 6 & Pestisida $(P)$ & $-0,0045$ & $-0,08^{n}$ \\
\hline 7 & Pendidikan (ED) & 0,2452 & $3,74^{\mathrm{a}}$ \\
\hline 8 & Pengalaman (EX) & 0,2899 & $3,42^{\mathrm{a}}$ \\
\hline 9 & Status $\left(D_{1}=1\right.$ : penyewa) & $-0,4069$ & $-8,45^{\mathrm{a}}$ \\
\hline 10 & Pelatihan $\left(D_{2}=1\right.$ : setelah $)$ & 0,1179 & $3,49^{\mathrm{a}}$ \\
\hline & $R^{2}$ & 0,8895 & \\
\hline & $\mathrm{F}$ & $96,56^{a}$ & \\
\hline
\end{tabular}

Tabel 1 menunjukkan bahwa produksi kedelai 89\% ditentukan oleh luas lahan, penggunaan benih, penggunaan tenaga kerja, pengeluaran untuk pupuk, pengeluaran untuk pestisida, pendidikan petani, pengalaman petani, status petani, dan dampak mengikuti pelatihan. Secara keseluruhan faktor-faktor tersebut berpengaruh sangat signifikan karena F-hitung jauh lebih besar dari F-tabel pada tingkat kepercayaan 0,01. Secara parsial (faktor lain dijaga tetap), luas lahan berpengaruh sangat signifikan, yaitu dengan meningkatnya penggunaan lahan sebesar satu persen dari sebelumnya akan meningkatkan produksi sebesar $0,52 \%$. Ini jelas dapat terjadi karena jika pengusahaan semakin luas maka produksi semakin tinggi. Penggunaan benih berpengaruh sangat signifikan terhadap produksi, yaitu dengan meningkatnya penggunaan benih sebesar satu persen akan meningkatkan produksi sebesar $0,28 \%$. Keadaan ini menunjukkan bahwa sebenarnya petani masih kurang dalam menggunakan benih kedelai. Jika petani telah menggunakan jumlah benih sesuai dengan anjuran maka diduga beih yang digunakan mempunyai daya tumbuh yang rendah.

Penggunaan tenaga kerja secara signifikan berpengaruh terhadap produksi kedelai, yaitu meningkatnya penggunaan tenaga kerja sebesar satu persen akan meningkatkan produksi kedelai sebesar $0,13 \%$. Keadaan ini menunjukkan bahwa petani masih kurang intensif dalam menggunakan tenaga kerja. Satu hal penting adalah dalam penyediaan tenaga kerja di 
sektor pertanian sangat sulit, terutama di daerah yang dekat kota. Karena langkanya tenaga kerja pertanian ini diduga kebutuhan tenaga kerja kurang terpenuhi.

Penggunaan pupuk tidak berpengaruh terhadap produksi kedelai. Hal ini disebabkan oleh kenyataan bahwa kedelai sebenarnya sudah tidak perlu dipupuk lagi karena beberapa hal, antara lain lahan kedelai merupakan lahan bekas padi sehingga masih terdapat sisa pupuk yang cukup untuk kedelai, dan kedelai untuk mencukupi kebutuhan hara (khusus Nitrogen) dapat mengambil langsung daru udara dengan bantuan bintil akar. Jadi terlihat bahwa penggunaan pupuk pada kedelai tidak berpengaruh. Penggunaan pestisida juga tidak berpengaruh terhadap produksi. Keadaan ini dapat terjadi dengan dua keadaan yang berbeda yaitu: pada saat tersebut tidak terjadi serangan hama dan penyakit, sehingga penggunaan pestisida tidak mempunyai efek sama sekali. Penggunaan pestisida akan terlihat efeknya jika pada saat tersebut terjadi serangan hama dan penyakit. Keadaan yang kedua adalah pestisida sudah tidak manjur lagi dalam mengatasi serangan hama dan penyakit, sehingga penggunaan pestisida juga tidak berpengaruh. Dalam kasus ini, yang terjadi adalah pada saat tersebut tidak terjadi serangan hama yang berat sehingga kedelai masih berproduksi.

Tingkat pendidikan Petani berpengaruh sangat nyata terhadap produksi kedelai, yaitu dengan meningkatnya lama pendidikan sebesar satu persen menyebabkan produksi kedelai naik sebesar $0,25 \%$. Pengalaman petani berpengaruh sangat nyata terhadap produksi kedelai, yaitu dengan bertambahnya penalaman petani sebesar satu persen menyebabkan produksi kedelai naik sebesar 0,29\%. Pendidikan formal petani penting karena merupakan peningkatan sumberdaya manusia (Kasri, 2011). Dengan pendidikan yang lebih tinggi, petani akan cepat menerima teknologi baru sebagai proses difusi.

Status petani berpengaruh sangat nyata terhadap produksi kedelai. Status petani sebagai penyewa berproduksi lebih rendah dibanding dengan petani yang berstatus pemilik. Status petani sangat menentukan dalam alokasi sumberdaya. Biasanya petani penyewa memperoleh kualitas lahan yang lebih rendah dibanding dengan petani pemilik. Gejala ini disebabkan oleh keadaan bahwa lahan yang akan disewakan kepada orang lain kualitasnya lebih rendah. Sedangkan lahan yang diolah sendiri mempunyai kualitas lahan yang lebih baik (Gathak, 1990). Hasil penelitian di Nepal menunjukkan bahwa perbedaan status petani terhadap akses lahan mempengaruhi alokasi penggunaan pupuk dan tenaga kerja (Acharya, 1999).

Pelatihan berpengaruh sangat nyata terhadap peningkatan produksi kedelai. Produksi kedelai meningkat setelah petani mengikuti pelatihan. Pelatihan perpengaruh positif terhadap produksi kedelai, baik pada fungsi produksi Cobb-Douglas maupun yang diperluas. Secara teoritis keadaan ini memang yang diharapkan. Implikasi lanjut dengan peningkatan produksi kedelai ini adalah meningkatnya produk marjinal dari semua input yang berpengaruh positif. Peningkatan nilai produk marjinal ini merupakan peningkatan produktivitas untuk semua input yang berpengaruh positif (Pyndick dan Rubinfeld, 2008), yang dalam hal ini adalah input modal dan tenaga kerja pada fungsi produksi CobbDouglas; dan input lahan, benih dan tenaga kerja pada fungsi produksi yang diperluas. Keadaan ini menunjukkan bahwa dengan pelatihan menyebabkan produktivitas dari modal, lahan, benih dan tenaga kerja menjadi meningkat. Sumberdaya manusiam yang dalam hal ini adalah petani, juga meningkat karena sebagian besar tenaga kerja yang digunakan berasal dari tenaga sendiri. Jadi dalam hal ini pelatihan telah meningkatkan sumberdaya manusia melalui peningkatan produk marjinal dari tenaga kerja. Sesuai dengan teori, bahwa dengan latihan akan meningkatkan nilai sumberdaya, melalui peningkatan produk marjinal tenaga kerja (Ehrenberg dan Smith, 2005).

Jika ditelusuri lebih lanjut, meningkatkan produksi kedelai setelah pelatihan antara lain disebabkan oleh karena petani lebih efisien dalam alokasi input melalui penerapan teknik bercocok tanam yang sehat, perbaikan cara budidaya lebih baik yaitu dengan menggunakan jarak tanam yang teratur, cara tanam yang lebih baik, waktu pemupukan yang tepat, penggunaan mulsa, dan pengamatan tanaman yang lebih baik serta pengambilan keputusan dalam pengendalian hama dan penyakit. Perbaikanperbaikan tersebut diperoleh petani setelah mengikuti pelatihan. 


\section{Fungsi Keuntungan}

Seperti dijelaskan sebelumnya bahwa produksi bukan merupakan tujuan pokok jika ditinjau dari sudut pandang usahatani. Usahatani akan berorientasi kepada keuntungan yang maksimum. Faktor yang dapat meningkatkan produksi belum tentu akan meningkatkan keuntungan. Oleh karena itu perlu diketahui faktor yang mempengarui keuntungan usahatani kedelai. Hasil estimasi keuntungan dapat dilihat pada Tabel 3, yang menunjukkan bahwa $66 \%$ variasi keuntungan usahatani kedelai ditentukan oleh luas lahan, penggunaan benih, penggunaan tenaga kerja, pengeluaran untuk pupuk, pengeluaran untuk pestisida, pendidikan petani, pengalaman petani, status petani, dan dampak mengikuti pelatihan. Secara keseluruhan faktor-faktor tersebut berpengaruh sangat signifikan karena $F$-hitung jauh lebih besar dari $F$-tabel pada tingkat kepercayaan 0,01 .

Secara parsial, luas lahan berpengaruh sangat signifikan terhadap keuntungan usahatani kedelai, yaitu meningkatnya luas pengusahaan sebesar satu hektar akan meningkatkan keuntungan sebesar Rp 3.796.470 per musim.

Keadaan ini mudah dipahami karena lahan merupakan cermin dari skala usaha. Jika skala usaha ditingkatkan maka keuntungan juga akan meningkat. Penggunaan benih secara signifikan berpengaruh terhadap keuntungan usahatani kedelai, yaitu meningkatnya penggunaan behih sebesar satu $\mathrm{kg}$ akan meningkatkan keuntungan sebesar Rp 42.157. Penggunaan tenaga kerja secara signifikan berpengaruh terhadap keuntungan kedelai, yaitu dengan menambah tenaga kerja satu orang, akan meningkatkan keutungan naik sebesar $\mathrm{Rp}$ 10.788. Jika penggunaan tenaga kerja dari dalam keluarga sendiri maka diperoleh manfaat ganda yaitu tambahan keuntungan usahatani dan tambahan pendapatan karena penghematan upah tenaga kerja. Penggunaan pupuk berpengaruh negatif signifikan terhadap keuntungan usahatani kedelai, artinya bahwa penggunaan pupuk menyebabkan keuntungan turun. Keadaan ini dapat dijelaskan bahwa penggunaan pupuk tidak menyebabkan produksi naik, tetapi dengan pasti menyebabkan peningkatan biaya produksi sehingga menurunkan keuntungan. Setiap penambahan penggunaan pupuk senilai $\mathrm{Rp}$ 10.000,00 akan menyebabkan keuntungan berkurang $\mathrm{Rp}$. 2.885. Jadi untuk meningkatkan keuntungan usahatani kedelai dapat dilakukan dengan mengurangi pengeluaran untuk pupuk. Pada batas tertentu, pengurangan ini juga tidak menyebabkan produksi turun secara signifikan.

Penggunaan pestisida seperti halnya dengan pupuk pengaruhnya negatif signifikan terhadap keuntungan kedelai. Artinya bahwa penggunaan pestisida menyebabkan keuntungan turun. Setiap peningkatan penggunaan pestisida senilai Rp 10.000,00 akan menyebabkan keuntungan turun sebesar $\mathrm{Rp}$ 105.264. Keadaan ini terjadi karena pestisida sudah tidak meningkatkan produksi lagi (lihat hasil estimasi fungsi produksi). Penurunan keuntungan yang lebih besar dari nilai pestisida yang dikeluarkan mengindikasikan bahwa penggunaan pestisida menurunkan produksi kedelai. Dengan demikian, pestisida sudah tidak perlu digunakan lagi. Teknologi PHT menyarankan agar penggunaan pestisida dikurangi dan deiganti dengan teknikteknik budidaya tanaman yang sehat. Jadi pengurangan penggunaan pestisida akan memberi dampak yang lebih baik, baik terhadap ekonomi petani maupun kesehatan, dan lingkungan. Dalam hubungannya dengan kesehatan dan lingkungan telah banyak bukti bahwa pestisida menurunkan kesehatan petani (Mariyono, 2009).

Pendidikan formal dan pengalaman petani berpangaruh secara signifikan terhadap keuntungan usahatani kedelai. Setiap peningkatan pendidikan selama satu tahun akan menyebabkan peningkatan keuntungan sebesar Rp 27.832; dan setiap tambahan pengalaman selama satu tahun akan meningkatkan keuntungan sebesar Rp 31.745. Pengalaman dan pendidikan formal memungkinkan petani lebih cepat dalam mengadopsi teknologi pertanian. Adopsi 
teknologi ini yang menyebabkan tingkat pendidikan formal dan pengalaman secara tidak langsung dapat meningkatkan produksi pertanian, termasuk kedelai.

Tabel 2. Hasil estimasi faktor yang mempengaruhi keuntungan

\begin{tabular}{llrr}
\hline No & Variabel independen & $\begin{array}{c}\text { Koefisien } \\
\text { Regresi }\end{array}$ & $\begin{array}{c}\text { Nilai t- } \\
\text { hitung }\end{array}$ \\
\hline 1 & Konstanta & -2.997 .360 & $-13,03^{\mathrm{a}}$ \\
2 & Luas lahan $(L)$ & 3.796 .470 & $8,42^{\mathrm{a}}$ \\
3 & Benih $(B)$ & 42.157 & $6,56^{\mathrm{a}}$ \\
4 & Tenaga kerja $(M)$ & 10.788 & $2,13^{\mathrm{a}}$ \\
5 & Pupuk $(F)$ & -2.885 & $-2,22^{\mathrm{a}}$ \\
6 & Pestisida $(P)$ & -105.264 & $-4,48^{\mathrm{a}}$ \\
7 & Pendidikan $(E D)$ & 27.833 & $1,50^{\mathrm{b}}$ \\
8 & Pengalaman $(E X)$ & 31.745 & $8,46^{\mathrm{a}}$ \\
9 & Status $\left(D_{1}=1\right.$ : penyewa) & -243.891 & $-1,89^{\mathrm{b}}$ \\
10 & Pelatihan $\left(D_{2}=1\right.$ : setelah) & 693.810 & $17,53^{\mathrm{a}}$ \\
\hline & $\mathrm{R}^{2}$ & 0,6644 & \\
& $\mathrm{~F}$ & $23,76^{\mathrm{a}}$ & \\
\hline
\end{tabular}

Sumber: analisis data primer
Variabel dependen: keuntungan usahatani kedelai (Rp); ${ }^{a}$ )
signifikan pada 0,$01 ;{ }^{b}$ ) signifikan pada 0,05

Status petani terhadap kepemilikan lahan secara signifikan berpengaruh negatif terhadap keuntungan kedelai. Adanya perbedaan status ini menyebabkan peberdaan keuntungan sebesar Rp 243.891. Ada dua penyebab terjadinya perbedaan ini, yang pertama adalah karena perbedaan ini menyebabkan produksi kedelai yang berbeda, dan yang kedua untuk penyewa lahan perlu mengeluarkan tambahan biaya yaitu sewa lahan. Adanya pelatihan memberikan pengaruh yang sangat signifikan terhadap peningkatan keuntungan usahatani kedelai.

Pelatihan telah menyebabkan keuntungan usahatani meningkat sebesar Rp 693.810. Keadaan ini sesuai dengan yang diharapkan bahwapelatihan akan meningkatkan keuntungan melalui peningkatan efisiensi ekonomi proses produksi kedelai. Temuan ini sesuai dengan teori ekonomi manajerial dari Salvatore (2007) yang menyatakan bahwa perbaikan manajerial pelaku binis akan dapat memperbaiki keutungan. Dampak pelatihan juga diperlihatkan oleh Gunawan et al. (2011) bahwa petani kedelai peserta pelatihan pengelolaan tanaman terpadu (PTT) menunjukkan keuntungan 40\% lebih tinggi dibanding petani yang tidak dilatih. Namun keadaan ini tentunya kurang dapat dipercaya karena petani PPT sebelum pelatihan sudah lebih maju dari petani yang tidak dilatih. Hal ini berdasarkan kenyataan bahwa petani peserta program pemerintah tidak dipilih secara random (Feder et al., 2004b).

\section{SIMPULAN}

Sehubungan dengan usaha peningkatan produksi kedelai di Indonesia, telah dilakukan pelatihan petani kedelai. Pelatihan kepada petani tersebut telah berdampak positif terhadap kinerja usahatani. Peningkatan kinerja usahatani ditunjukkan oleh adanya peningkatan produksi dan keuntungan usahatani Peningkatan produksi terjadi karena penggunaan input-input (sarana produksi) yang lebih produktif. Peningkatan keuntungan merupakan akibat langsung dari peningkatan produksi dan penggunaan input yang lebih efektif dan efisien. Temuan-temuan lain yang juga penting dalam penelitian ini adalah kualitas sumberdaya manusia yaitu pendidikan formal dan pengalaman sebagai petani yang sangat berpengaruh terhadap produktivitas dan keuntungan usahatani kedelai. Petani yang berstatus penyewa menunjukkan produksi dan keuntungan yang lebih rendah dibandingkan dengan petani pemilik.

\section{DAFTAR PUSTAKA}

Acharya, R.N., 1999. The Impact of share tenancy on resource allocation: evidence from Nepal. American Agricultural Economics Association, 81 (December): 1309

Agro-Chemical Report, 2002. Pesticide and policy: the impact of integrated pest management (IPM) on the Indonesian economy. Agro-Chemical Report, 2,1820.admin/uploadedfiles/Technological Change in Agriculture and Povert.htm

Arisudi, M Azis; Gapor, S Abdul, 2008. The competitiveness of soybean production in Blitar-East Java, Indonesia. Jurnal Ekonomi Pembangunan, 9 (2): 228 - 247

BPS, 2010. Indonesia Year Book. Badan Pusat Statistik, Jakarta

BPS, 2011. Indonesia Year Book. Badan Pusat Statistik, Jakarta

Ehrenberg, RG. dan Smith, RS. 2005. Modern Labor Economics: Theory and Public Policy, $9^{\text {th }}$ edition. Prentice Hall, 672h. 
Feder, G. dan Savastano, S., 2006. The role of opinion leaders in the diffusion of new knowledge: the casa of integrated pest management. World Development, 34, $1287-1300$

Feder, G., Murgai, R. dan Quizon, J.B., 2004a. The acquisition and the diffusion of knowledge: the case of pest management training in farmer field schools, Indonesia. Journal of Agricultural Economics, 55: 217-239.

Feder, G., Murgai, R. dan Quizon, J.B., 2004b. Sending farmers back to schools: the impact of farmer field school in Indonesia. Review of Agricultural Economics 26): 45-62.

Gathak, S., 1994. Pertanian dan Pembangunan Ekonomi. Dalam: Gemmell, Norman (Ed). Ilmu Ekonomi Pembangunan. LP3ES, Jakarta, 491-536

Gittinger, J.P., 1982. Economic Analysis of Agricultural Projects. The John Hopskin University Press. Baltimore.

Godtland, E. M., Sadoulet, E., de Janvry, A., Murgai, R., dan Ortiz, O., 2004. The impact of farmer field schools on knowledge and productivity: a study of potato farmers in Peruvian Andes. Economic Development and Cultural Changes, 53: 63-92.

Gunawan, Handoko dan Asnita, R., 2011. Peningkatan keuntungan usaha tani kedelai melalui PTT di Bojonegoro. Prosiding Seminar Nasional: Inovasi untuk Petani dan Peningkatan Daya Saing Produk Pertanian, h. 502-505. ISBN 978-979-3450-28-5.

Irham, 2001. Impact of IPM program on rice production and income. In Toward the harmonization between development and environmental conservation in biological production. Proceeding of the International Workshop, The University of Tokyo, Japan.

Irham. 2002. Integrated pest management program, pesticide use and rice productivity: A case study in Yogyakarta, Indonesia. In A. Herrmann \& S. Schumann (Eds.), Proc. Int. Workshop on Environmental Risk AssessmentofPesticides and Integrated Pesticide Management in Developing Countries (pp. 73-81). Braunschweig, Germany: Landschaftsökologie und Umweltforschung, 38 .

Kasri, R.A. 2011. Time series evidence on education and economic growth in Indonesia. Economic Journal of Emerging Markets, 3 (2): 109-123

Lilja, N. dan Dixon, J., 2008. Operationalising participatory research and gender analysis: new research and assessment approaches. Development in Practice, 18: 467-478

Mancini, F. dan Jiggins, J., 2008. Appraisal of methods to evaluate farmer field schools. Development in Practice, 18: 539-550.

Mariyono, J. dan Kuntariningsih, A., 2007. Keunggulan ekonomi, penerapan teknologi PHT dan sosial ekonomi usahatani padi beririgasi teknis di Kecamatan Moyudan, Jogjakarta. Jurnal Studi Ekonomi, 2 (2): 155-168.

Mariyono, J. dan Kuntariningsih, A., 2009. Gender analysis of demand for health services in rural areas of Java, Indonesia. Journal of Rural Development, 28 (3): 317-326.

Mariyono, J. dan Rachmansyah, Y., 2010. Dampak sekolah lapangan pengendalian hama terpadu pada produksi kedelai di Jawa Timur: analisis ekonomi. Dinamika Sosial Ekonomi, 6 (2): 129-144

Mariyono, J., 2006. Kontribusi teknologi pengendalian hama terpadu pada penurunan penggunaan pestisida: kasus produksi padi di Yogyakarta. Jurnal Matematika, Sains dan Teknologi, 7 (2): 128-138.

Mariyono, J., 2009. Integrated pest management training in Indonesia: 
does the performance level of farming training matter? Journal of Rural and Community Development, 4: 93-104.

Mariyono, J., 2011. Impact of integrated pest management training on the efficiency of soybean-base agribusiness in East Java. Jurnal Ekonomi dan Bisnis, 1 (2): 2011

Mariyono, J., Kompas, T. dan Grafton, R.Q., 2010. Shifting from Green Revolution to environmentally sound policies: technological change in Indonesian rice agriculture. Journal of the Asia Pacific Economy, 15: 128-147.

Pimentel, D., 2012. World overpopulation. Editorial. Environment, Development and Sustainability, 14 (2):151-152

Pindyck, R. dan Rubinfield, D., 2008. Microeconomics, $7^{\text {th }}$ edition . Prentice Hall | ISBN-10: 0132080230, 768h.

Pretty, J. and Waibel, H., 2005. Paying the price: the full cost of pesticides, dalam: J.N. Pretty (ed.), The Pesticide Detox: Towards a More Sustainable Agriculture, Earthscan, London, pp. 39-54.
Rölling, N. dan van de Fliert, E., 1994. Transforming extension for sustainable agriculture: the case of integrated pest management in rice in Indonesia. Agricultural and Human Value, 11 (2/3): 96-108

Salvatore, D. 2007. Managerial Economics: Principles and Worldwide Applications, $6^{\text {th }}$ edition. Oxford University Press, USA, 656h.

van den Berg, H., 2004. IPM Farmer Field Schools: A Synthesis of 25 Impact Evaluations. Wageningen University, The Netherlands, $53 \mathrm{~h}$.

van den Berg, H., and Jiggins, J., 2007. Investing in farmers - the impacts of farmer field schools in relation to integrated pest management. World Development, 35 (4): 663-686.

Wooldridge, J.M., 2009. Introductory Econometrics: A Modern Approach. South-Western Congade Learning, Mason USA, 865h.

Yamazaki, S. dan Resosudarmo, B.P., 2008. Does sending farmers back to school have an Impact? Revisiting the issue. Developing Economies, 42: 153-150. 